\title{
ARTICLE
}

\section{Trends and Causes of Deterioration in the Shallow Groundwater Conditions in an Arid Agriculture Area through GIS-based Spatial Hydrochemical and Hydrodynamics Modeling}

\author{
Alaa A. MASOUD \\ Geology Department, Faculty of Science, Tanta University, 31527 Tanta, EGYPT. e-mail: alaamasoud@hotmail.com.
}

(Received: 29 December 2012; Accepted: 21 January 2013)

\begin{abstract}
Spatio-temporal dynamics and hydrochemistry of the shallow groundwater aquifers underlying the recently reclaimed lands in Tahrir, Wadi El-Natrun, and Burg Al-Arab areas, located west of the Nile Delta region of Egypt are investigated. The prime objective was to understand causes and propose proactive controls by monitoring changes occurred using the available data. Groundwater samples from 134 sites were collected in 2006-2007 period. Parameters describing temperature, $\mathrm{pH}$, electrical conductivity (EC) and total dissolved solids are in-situ recorded using portable meters. Major elements of the cations $\left(\mathrm{K}^{+}, \mathrm{Na}^{+}, \mathrm{Ca}^{2+}\right.$, and $\left.\mathrm{Mg}^{2+}\right)$ and anions $\left(\mathrm{SO}_{4}{ }^{2-}, \mathrm{HCO}_{3}^{-}, \mathrm{Cl}^{-}\right.$, and $\left.\mathrm{NO}_{3}^{-}\right)$were carried out. Analysis of the groundwater samples was then performed to derive Sodium Adsorption Ratio (SAR), water types, and water quality according to the SAR against EC. The in-situ measured and estimated groundwater variables were then analyzed with the ordinary kriging implemented in the geostatistical analyst of the ArcGIS9.3 package. The experimental semivariograms and the best-fitted models for all variables were built based on trial and error parameter selection. Models attained the best goodness of fit were selected for interpreting the results. Results indicated warning levels of water table, salinity, nitrates, water types, and water quality. Spatio-temporal variations and the controlling factors are characterized over the studied areas. Based on the results, measures are proposed by taking into consideration of the local specific attributes affecting the groundwater conditions for each area. The proactive and the ameliorative measures are expected to predict impacts that may rise from the region's acute water scarcity and quality deterioration in the near future.
\end{abstract}

Keywords : Environmental degradation, Groundwater, Hydrodynamics, Hydrochemistry, Nile Delta of Egypt Decision Planning (ERDP)

\section{Introduction}

Egypt's high rate of population growth coupled with expansion in industrial, agricultural and tourism activities has resulted in an increased burden on the country's limited water resources that have in turn adversely affected the public health and many environmental problems arose. The population was doubled in the last 40 years from 33 million in 1965 to 67 million in 2001 and is expected to reach between 90-100 million in 2025 increasing the need for the scarce water and arable land. National Water Resources Plan (NWRP) 2017 in Egypt predicted a groundwater abstraction increase from 5.1 $\mathrm{BCM} / \mathrm{yr}$ in 1997 to $11.3 \mathrm{BCM} / \mathrm{yr}$ in 2017 to meet the water demand. In 1997, Egypt already fell below the poverty limit of $1,000 \mathrm{~m}^{3} / \mathrm{yr}$, the trend will continue to reach the critical levels of $720 \mathrm{~m}^{3} / \mathrm{yr}$ water per capita in 2017. Environmental degradation due to water quality was found to be $1.8 \%$ of GDP of the country.

Water quality degradation is commonly intensified in the shallow aquifers underlying agricultural fields surrounding urban centers where exploitation has been historically undertaken without proper concern for the environmental impacts or even the concept of sustainable yield. This is true in the newly reclaimed areas located west of the Nile Delta of Egypt which represent typical agricultural area in arid environment where water resources are vital for the sustainable development of the area. Reclamation project of such desert region has met a great success when commenced in 1959. Since its commencement and for some decades, the project relied mainly on groundwater from relatively deep wells $(60-100 \mathrm{~m})$ from the Pleistocene aquifer. Later, when a network of water courses and surface canals has been set, irrigation has been shifted to the abundant and freely available surface water. With the rapid intensification of reclamation practices further to the west and south in the desert, many wells have been dug to secure groundwater during the surface water shortage and for fields distant from irrigation canals. 
Ambitious efforts from the government side are ongoing to dig new canals to suffice water demands for past and future reclamation projects. However, efforts are costly and mostly hampered by the rolling topography. Recently cultivated areas rely on the extensive use of groundwater for domestic and irrigation. Intensification of agricultural practices intertwined with the high consumption of fertilizers, the overuse of surface water, and the rapidly growing abstraction rates from groundwater have led to alterations in the aquifer conditions. These have affected water suitability and hence the agricultural productivity in the area (Masoud and Atwia, 2010). A dire clear knowledge of the groundwater dynamics, hydrochemical composition and their relation with land features and human interventions become indispensable to sustain future groundwater resources. This concept could help demarcate the at-risk areas, enable gain much insight into the controlling factors, and set measures to combat for the future environmental consequences.

This assessment can involve hydrogeologic and geologic variables, topography, and landuse/landcover. Due to its complexity, the use of analytical or numerical modeling, along with geographic information systems (GIS) is essential to manipulate the large amounts of spatial data, in particular, when underpinned with the use of the multispectral remote sensing technology, all integrated and tested for the first time in the region west of the Nile Delta.

\section{Study Areas}

The study areas (Fig. 1) share their being recent agricultural and urban expansion centers and differ greatly in their land uses and covers, geomorphology, and geographic position to the Nile Delta and the Mediterranean Sea including Wadi El-Natrun (Fig. 2), Tahrir (Fig. 3), and Burg Al-Arab (Fig. 5) areas. The whole region is dominated by semi-arid to arid climatic conditions and characterized by scarce rainfall and high temperatures for a considerable part of the year. The regional geology comprises mainly of a sedimentary succession that ranges in age from Late Cretaceous to Quaternary (e.g., Shata, 1955; Sanad, 1973; Omara and Sanad, 1975; El-Shazly et al., 1978; Rashed et al., 1989).

In Natrun area, Quaternary alluvial deposits as well as Pliocene sediments covers mainly the surface. These are underlain by Miocene carbonates and clastics that in turn overlie a thick sedimentary column of earlier Cenozoic and Mesozoic sediments (Hantar, 1990). The Upper Pliocene sediments show alternating clay, loam, sand, and marl ranging from fluvial plain to near shore deposits (Rashed, 1991). According to Rashed (1991) the clay minerals are smectite, pure or with minor illitic layers (mixed layer) not exceeding 20\%, illite (5-20\%) and

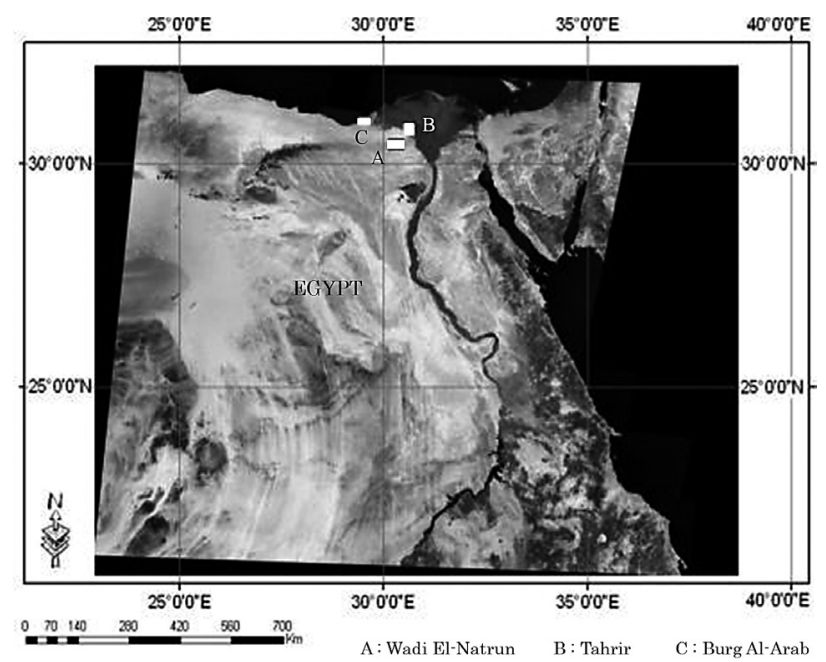

Fig.1. Locations of the studied areas shown on Landsat mosaic of Egypt; Wadi El-Natrun (A), Tahrir (B), and Burg Al-Arab (C).

kaolinite (5-15\%). NW-SE folding and faulting systems are also prevalent.

In Tahrir area, the stratigraphic sequence comprises mainly of superficial alluvial quaternary sediments (Fig. 4) and the underlying Pleistocene strata. The quaternary sediments constitute the young and old alluvial plains of the Nile Delta. The young alluvial plain occupies the narrow strip of the fertile cultivated lands close to Rosetta branch and comprises mainly of clay and silt. To the west, where most of the area belongs to the rolling old plain, stabilized sand dunes, quaternary sands, and prenile sediments of coarse sand and gravel are dominant. The Pleistocene deltaic sediments consist mainly of sand and gravel with thin intercalations of clay. The deltaic lagoonal deposits are also present in the subsurface with a thickness up to $15 \mathrm{~m}$ of gypsiferous dark grey to brown sticky clay and sand (Abdel Baki, 1983).

Burg Al-Arab area is characterized by the presence of two elongated ridges and a piedmont plain confining two depressions parallel to the present shoreline, the beach occupying the narrow zone lying between the low and high tidal zones (Fig. 5). Alluvial Holocene loamy deposits prevail on the depression floor where cultivation practices are dominated. These are composed of quartz sand, silt and clay with abundant carbonate grains in the north while pebbles and gravels are abundant to the south. The relatively high silt content in the soil is the main cause of their noticeably high water holding capacity. The alluvial layer is interbedded in the subsurface with lagoonal stratum composed mainly of shell debris of bivalves, echinoids, algae and forams, in addition to calcareous ooids and pellets with few clay and quartz grains. Strata of thick Holocene sabkha and marsh deposits composed of 1-2 m brownish-yellow calcareous muddy loams and (5-8 m) grey gypsiferous deposits were also recorded 


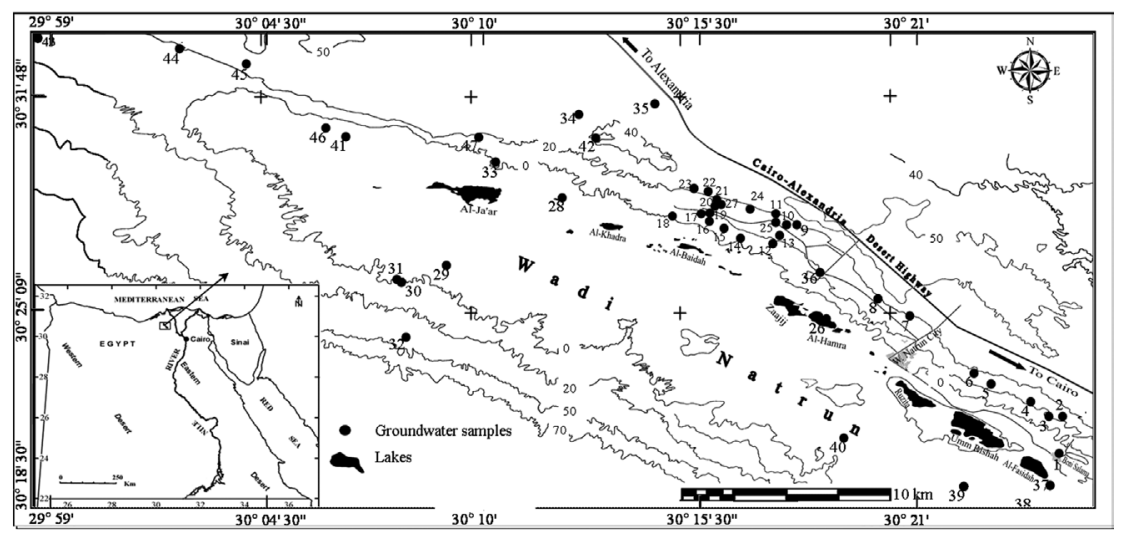

Fig. 2. Physiography and sampling locations in Wadi El-Natrun area.

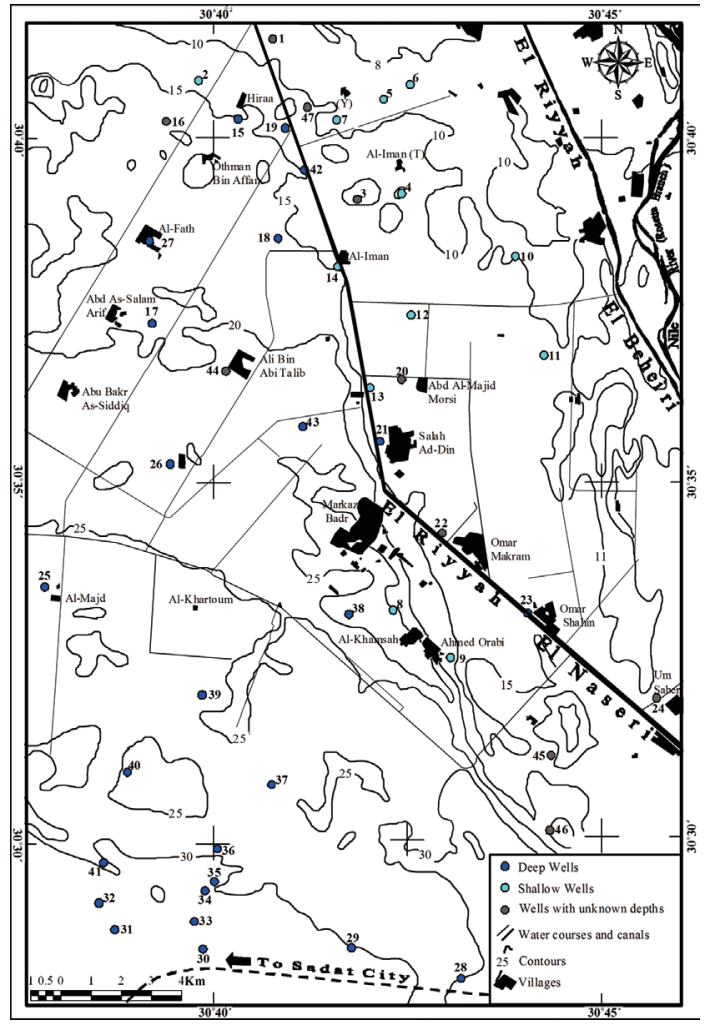

Fig. 3. Physiography and sampling locations of Tahrir area.

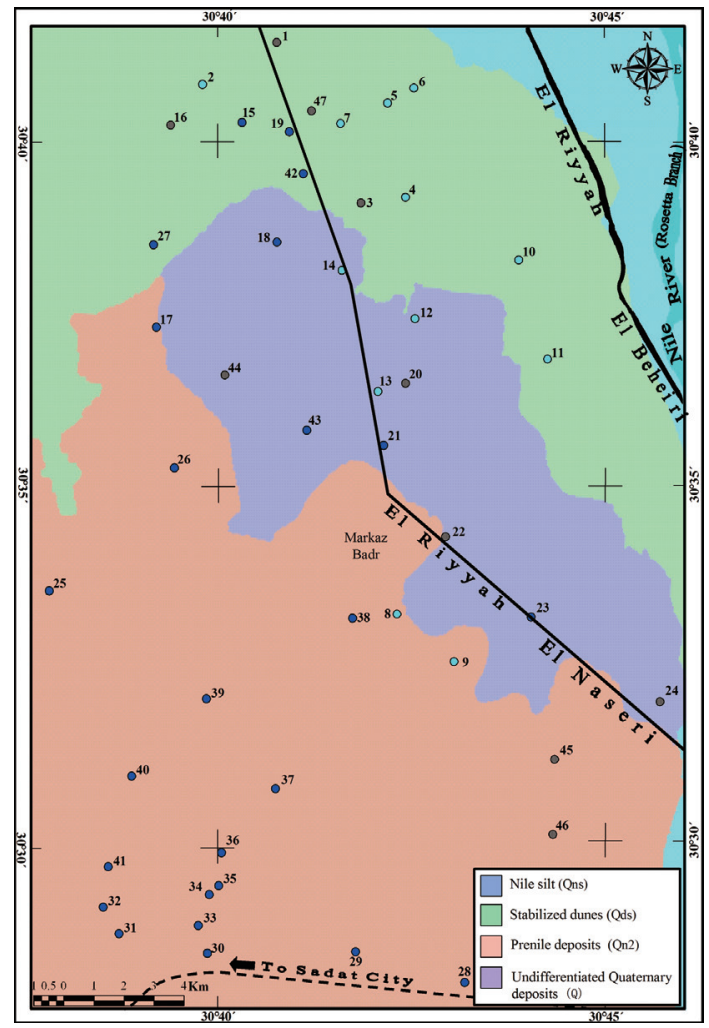

Fig. 4.Geological map of the Quaternary sediments (modified after CONOCO (1987)).

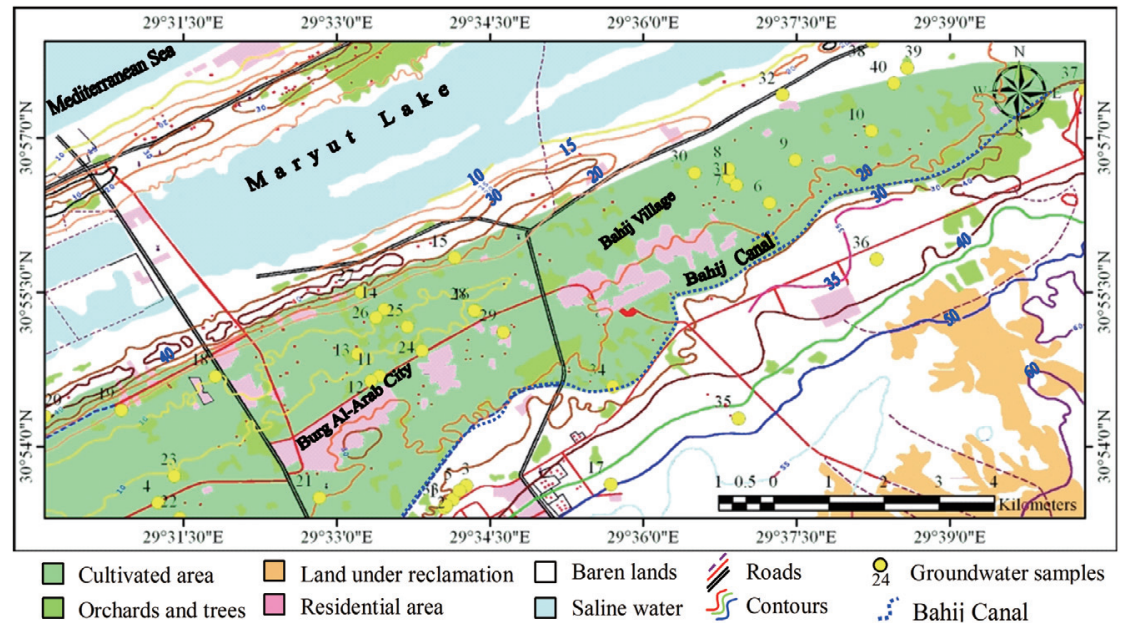

Fig. 5. Physiography and sampling locations in Burg Al-Arab area. 
(Ali and West, 1983; Stanley and Hamza, 1992).

The studied aquifer systems are Pliocene (Wadi El-Natrun) and Pleistocene (Tahrir and Burg Al-Arab) age. More details on these aquifers are explained in the next section.

\section{Aquifer Systems}

\section{1. Pliocene aquifer}

According to Abdel-Baki (1983), the Pliocene section in Wadi El-Natrun area has a thickness of about $140 \mathrm{~m}$ and two water-bearing horizons: the upper semi-confined horizon (about $25 \mathrm{~m}$ thick) is composed of sand, clay, and interbeds of limestone, and the lower confined horizon (about $24 \mathrm{~m}$ thick) is dominated by sands, dark mudstones, and shale especially at the base. The two units are separated by a thick clay layer that changes laterally to sandy layers towards the south and east allowing the interconnection of water in the two horizons. However, wells are designed to obtain water either from the two water bearing horizons or from one of them.

The aquifer acts as a natural discharge area and there is a lateral flow from the surrounding hydraulically-connected aquifers: the Pleistocene aquifer from the east and the Moghra Miocene aquifer from the west and south. Natural recharges also come from percolation of the excess irrigation water in the newly reclaimed lands as well as from the rare and intermittent rainfall storms, and some contribution from palaeo-water of the Western Desert (Awad et al., 1997). The Pliocene sediments are variable in lithology laterally and vertically, and thus a wide range of the hydraulic characteristics are expected in the aquifer. However, few pumping tests were carried out in Wadi El-Natrun. The averages of the transmissivity and storativity of the aquifer are about $420 \mathrm{~m}^{2} / \mathrm{d}$ and $7.5 \times 10^{-4}$, respectively (General Petroleum Company, 1978; RIGW, 1990). The aquifer in general showed a moderate productivity and fair quality of the groundwater (RIGW, 1992). Discharges occur mainly through direct abstraction for agricultural and domestic purposes, spring flow, seepage to the salty lakes, evapotranspiration, and interaquifer flow.

\section{2. Pleistocene aquifer}

In Tahrir area, the Pleistocene aquifer consists of graded sand and gravel with thin interbeds of clay. Its thickness varies from $120 \mathrm{~m}$ near the southern boundary to more than $230 \mathrm{~m}$ in the center (RIGW, 1990). Groundwater is under phreatic conditions because it is directly recharged from the main reservoir underlying the Nile Delta (Abdel Baki, 1983, Saad, 2001), which is hydraulically connected to the aquifer. It is also recharged by the surface seepage from the new cultivated lands as well as from the main irrigation canals. The main discharge of the Pleistocene aquifer takes places vertically through pumping of a large number of groundwater wells as well as by evaporation and lateral flow. The hydraulic conductivity of the aquifer varies from 11 to $50 \mathrm{~m} / \mathrm{d}$ and the storativity ranges from $0.004-0.043$ (Abdel Baki, 1983; Saad, 2001).

In Burg Al-Arab area, the Pleistocene aquifer consists of oolitic limestone with average thickness of $37 \mathrm{~m}$ in the coastal plain, $43 \mathrm{~m}$ in the tableland, and a minimum thickness attainable in the frontal plain. Groundwater is under phreatic condition with water table close to the mean sea level. The aquifer rests on the already existing main water table initially formed from seawater intrusion underpinned with the overpumping from the aquifer. The aquifer attains a hydraulic conductivity of $19.6 \mathrm{~m} / \mathrm{d}$ (Hilmy et al., 1977) and a saturated thickness ranged between $19 \mathrm{~m}$ and $30 \mathrm{~m}$, effective porosity of $36.1 \%$ on average, and showed horizontal permeability of $549 \mathrm{mD}$ and vertical permeability of $405.2 \mathrm{mD}$ (El Shazly et al., 1978). Groundwater is recharged from the localized rainfall and percolation from the newly excavated irrigation canals (e.g. Bahij Canal). Most of the groundwater has been abstracted by large diameter wells that exceed $50 \mathrm{~m}$ in depth. The groundwater discharges naturally into the Maryut Lake, coastal marshes, salt lakes, and continues northward to the Mediterranean Sea. Another element of natural discharge is the downward leakage to the underlying Miocene aquifer (Hilmy et al., 1977).

\section{Data and Methods}

One hundred thirty four groundwater samples were collected from the studied areas: fourty seven samples from each of Tahrir (May 2006) and Wadi El-Natrun (June 2006), and forty samples from Burg Al-Arab (February 2007). APHA (1989) rules for sampling, preservation, and water analysis were followed. Portable meters were used to measure the temperature, $\mathrm{pH}$, Electrical Conductivity (EC) and Total Dissolved Solids (TDS) at the sampling site. Major elements of the cations $\left(\mathrm{K}^{+}\right.$, $\mathrm{Na}^{+}, \mathrm{Ca}^{2+}$, and $\mathrm{Mg}^{2+}$ ) and anions $\left(\mathrm{SO}_{4}{ }^{2-}, \mathrm{HCO}_{3}{ }^{-}, \mathrm{Cl}^{-}\right.$, and $\mathrm{NO}_{3}{ }^{-}$) were carried out at the geology department, faculty of Science, Tanta University in Egypt. The sampling points were carefully chosen to cover the whole range of the geomorphic, land cover/ use, and physiographic features in the studied areas. Analysis of the groundwater samples was then conducted to derive Sodium Adsorption Ratio (SAR), water types of Piper (1944), and water quality according to the SAR against EC of United States Salinity Laboratory Staff (1954). Geographic coordinates of sampling points were recorded with GARMIN GPS device and the groundwater variables were then analyzed with the ordinary kriging $(\mathrm{OK})$ implemented in the geostatistical analyst of the ArcGIS9.3 package. The experimental semivariograms and the best-fitted theoretical models for all variables were built based on trial and error parameter selection. The model fitness was 
evaluated statistically by minimum mean error (ME), root mean error (RME), and mean squared error (MSE), and root mean squared error (RMSE), and the best-fit semivariogram models were selected for OK calculations.

In order to quantitatively highlight temporal changes accompanying the agricultural cover in the studied areas, remotely-sensed imageries are georectified, enhanced, and classified. Color composites based on the optimum index factor (OIF) of Chavez (1982), Principal Component Analysis (PCA), and spectral indices that are designed to be correlated to vegetation: Normalized Difference Vegetation Index (NDVI) of Tucker (1979); Soil Adjusted Vegetation Index (SAVI) of Huete (1988) and Gao et al. (2000) and tasseled cap greenness index (Kauth and Thomas, 1976) have been integrated to classify the imageries.

\section{Results and Discussions}

Results are addressed separately for the studied areas and summarized here for comparison on various aspects of groundwater conditions.

\section{1. Temporal expansions}

The vegetation cover in Tahrir area (Fig. 6) showed fourfolds expansion between 1972 (4, 311 feddans) and 2006 (16,955 feddans). Agricultural expansions of four-folds (1984-2001) and eight-folds (1973-2007) occurred in Wadi El-Natrun (Fig. 10) and Burg Al-Arab areas, respectively. Rate of expansion was the highest in Wadi El-Natrun followed by Burg Al-Arab, and then Tahrir areas, markedly related to governmental rules for land possession, suitability of reclaimable lands, water resources availability, road network accessibility, and proximity to other supporting industrial and tourist activities.

\section{2. Hydrodynamics}

In general, flow patterns followed the regional topographic gradients in the studied areas. In Wadi El-Natrun, groundwater flows radially towards the lakes in the depression. As a result of the extensive withdrawal of groundwater a remarked decrease in water level has been noticed when the present water level records are compared with that of the 1990 data (RIGW, 1992). An average decrease of $15 \mathrm{~m}$ in the piezometric surface is clarified in the northwestern zone while the decline in the southeastern zone was subtle and averaged $1.5 \mathrm{~m}$. In Tahrir area, water table exceeds $22 \mathrm{~m}$ at its southwestern corner and flows northeastwardly to the Nile River. Groundwater in Burg Al-Arab flows northward towards Maryut Lake and the Mediterranean Sea. Local water table changes are related to the high discharge and/or recharge rates in the sediments of different permeability and hence of variant groundwater residence time. Relatively deeper piezometric surface is dominated under the urban areas mostly related to the pumping for domestic daily activities, while shallower surface is common under the cultivated land likely related to the return flow from irrigation and the higher recharge from the surface water, in particular, in Tahrir area.

\section{3. Hydrochemical characteristics}

Water types by Piper diamond diagram

Groundwater types were identified (Table 1) according to Piper diamond diagram (Piper, 1944). Wadi El-Natrun and Burg $\mathrm{Al}$-Arab samples are dominated by $\mathrm{NaCl}$ water types, while the sodium bicarbonates/sodium MIX prevailed in Tahrir (Fig. 7). This is most likely underpinned by the fresh water percolation from the intense network of surface canals of the old agriculture and the newly reclaimed lands, as well as from the rainfall.

Table 1. Water types of the studied areas.

\begin{tabular}{|llc|}
\hline Area & Water type & $\begin{array}{c}\text { No. of } \\
\text { samples }\end{array}$ \\
\hline \multirow{4}{*}{ Natrun } & $\mathrm{NaCl}$ & 34 \\
& $\mathrm{Na}\left(\mathrm{HCO}_{3}\right)$ and $\mathrm{Na} \mathrm{MIX}$ & 11 \\
& $\mathrm{Na}_{2} \mathrm{SO}_{4}$ & 2 \\
\hline \multirow{4}{*}{ Tahrir } & $\mathrm{Na}\left(\mathrm{HCO}_{3}\right)$ and $\mathrm{Na} \mathrm{MIX}$ & 31 \\
& $\mathrm{Ca}\left(\mathrm{HCO}_{3}\right)_{2}$ and $\mathrm{Mg}\left(\mathrm{HCO}_{3}\right)_{2}$ & 13 \\
& $\mathrm{Na}_{2} \mathrm{SO}_{4}$ & 2 \\
& $\mathrm{NaCl}$ & 1 \\
\hline Burg & $\mathrm{NaCl}$ & 25 \\
Al-Arab & $\mathrm{Na}_{2} \mathrm{SO}_{4}$ & 15 \\
\hline
\end{tabular}

Salinity

In Wadi El-Natrun, the samples were between fresh (TDS $<1,000 \mathrm{mg} / \mathrm{l}$ ) and brackish water (TDS 1,000 - 10,000 mg/ 1). Generally, the groundwater of the shallow wells showed higher TDS than the deep wells. The groundwater salinity of the southeastern part ranged from $241 \mathrm{mg} / \mathrm{l}$ (well 3) to $882 \mathrm{mg} /$ 1 (well 8) with the average of $424 \mathrm{mg} / \mathrm{l}$, with exceptions of wells no. 6 and 36 where the TDS reached 1,581 and 1,366 mg/ 1, respectively. The high salinity of groundwater in these wells is attributed either to the shallow depth of well (only $42 \mathrm{~m}$ in well $\log$ ) where the water is obtained only from the upper zone, or due to well condition (well 6) as this well is in operation since 1974 without any appropriate maintenance. However, the predominance of bicarbonate ion over the $\mathrm{Cl}^{-}$and $\mathrm{SO}_{4}{ }^{2-}$ ions indicates a fresh water recharge from the Pleistocene aquifer of the Nile Delta. Groundwater in the northwestern part showed an average TDS of 2,037 mg/l that varied from $619 \mathrm{mg} / \mathrm{l}$ at well 19 to more than $4,860 \mathrm{mg} / \mathrm{l}$ at well 30 . Groundwater of this zone is brackish of secondary salinity where the $\mathrm{Cl}^{-}$and $\mathrm{SO}_{4}{ }^{2-}$ salts are dominant. Thus is mainly attributed to leaching and dissolution processes occurring in the sediments, and the probable mixing of water from the Pliocene aquifer with deep saline water of the 
Miocene aquifer, due to over-pumping. High salinities of the Pliocene aquifer in general are due to the presence of lagoonal and marine clay beds of great thickness with high content of the inherited salts within the aquifer deposits, the salt lakes and marches, and the high rate of evaporation. The salinity tends to increase generally toward the northwest.

Tahrir iso-salinity map by OK (Fig. 8) clarified good correlation among the groundwater salinity, the distribution of surface water supplies, and the dominant sedimentary cover. Groundwater in the Quaternary sands marked with suitable surface water canals showed the very fresh water with salinity range from 213 to $601 \mathrm{mg} / \mathrm{l}$ (average of $386 \mathrm{mg} / \mathrm{l}$ ).

The average salinity of the prenile coarse sands and gravels is $693 \mathrm{mg} / \mathrm{l}$, with minimal values started from 201 and maximal reached at $1,363 \mathrm{mg} / \mathrm{l}$. In the prenile deposits covered by surface water canals the groundwater is fresh, while in areas free from the surface water supplies the salinity is high. The stabilized dunes showed a distinct case, salinity varied between 355 and 1,386 mg/l (average of $743 \mathrm{mg} / \mathrm{l}$ ). Quite good coverage of water canals exist and the groundwater, in general, is very fresh downward these canals. However, in the northern part, anomalously high salinity pockets occur at the east and west of El Riyyah El Naseri (e.g. wells 3, 4, 5, and 7). The water level and landcover maps, subsurface stratigraphy, and the well conditions were inspected in detail. The peizometric water table has reached the surface in these areas due to the relative abundance of water from both the water canals and the aquifer (i.e., high return flow from the irrigation and high discharge rates from the aquifer). The increased evapotranspiration from this water during the hot summer in such arid region has consequently resulted in salt concentration and hence increased salinity. Moreover, shallow clay lenses were found to dominate within the water bearing formation (i.e., long water level residence time). These factors, in addition to the ageing conditions of wells, either individually or combined has led to the prevalence of a waterlogging phenomenon and therefore an intense salinization both in the groundwater and the soil. Increase of salinity is expected to increase with the long term withdrawals of the groundwater. Low salinity of groundwater and predominance of bicarbonate for most water samples may attributed mainly to the influence of fresh water recharge from the Nile Delta aquifer and surface water.

In Burg Al-Arab area, the $\mathrm{NaCl}$ brackish water of TDS ranged from 1,670 to $16,500 \mathrm{mg} / 1($ mean $=4,319 \mathrm{mg} / \mathrm{l})$ and is influenced by $\mathrm{Cl}^{-}$(linear correlation coefficient $r=0.99$ ), $\mathrm{Na}^{+}$ $(r=0.98), \mathrm{Mg}^{2+}(r=0.89), \mathrm{SO}_{4}{ }^{2-}(r=0.87)$, and $\mathrm{Ca}^{2+}(r=0.66)$. The brackish water of the $\mathrm{Na}_{2} \mathrm{SO}_{4}$ type showed a TDS range from 2,390 to 9,540 mg/l (average of 4,234 mg/l) and exhibited strong correlation with $\mathrm{Na}^{+}(r=0.97), \mathrm{Cl}^{-}(r=0.86)$, and $\mathrm{SO}_{4}{ }^{2-}(r=0.78)$.
Nitrates

All groundwater samples from the studies area showed dissolved nitrates within the permissible limit of $45 \mathrm{mg} / 1$, except for three wells (samples 14, 37, and 47) located in the Tahrir area where the sample number 47 reached a maximum concentration of $62.92 \mathrm{mg} / \mathrm{l}$. Nitrates despite comply with the permissible limits were concentrated in the urban areas indicating the anthropogenic source from the improperly designed sewage system.

\section{Water uses}

If the salinity estimated from EC exceeds the threshold, crop growth is ceased and results in loss of yield. The SAR measures the abundance of $\mathrm{Na}^{+}$in relation to $\mathrm{Ca}^{2+}$ and $\mathrm{Mg}^{2+}$. Excess sodicity deteriorates soil structure and reduces water infiltration into the soil. Water quality and possible hazards are shown in Table 2. The groundwater of the Pliocene aquifer underlying Wadi El-Natrun area is dominated by high to very high salinity hazards and medium to very high alkali hazards. The samples from the Pliestocene aquifer in Tahrir area is characterized mainly by medium to high salinity hazards and low to medium alkali hazards (Fig. 9), while almost all of the samples from Burg Al-Arab area showed high to very high salinity and alkali hazards.

\section{4. Temporal quality changes}

In Wadi El-Natrun area, temporal change from the TDS data for 1973 (El-Hinnawy and Atwa, 1973), 1997 (El-Awady et al., 1997), to the present data, confirmed the secondary salinization of the groundwater where salinity of the $\mathrm{NaCl}$ types has increased and the $\mathrm{NaHCO}_{3} / \mathrm{NaMix}$ has been turned into $\mathrm{NaCl}$ types and therefore higher salinity. Comparison revealed also everelevated salinity and alkalinity hazards (Fig. 11) and worsened groundwater quality criteria (Masoud and Atwia, 2010).

Table 2 . Water quality classes and hazards.

\begin{tabular}{|cllc|}
\hline Area & Class & \multicolumn{1}{c}{ Hazard } & $\begin{array}{c}\text { No. of } \\
\text { samples }\end{array}$ \\
\hline & C4S3 & High salinity-high alkali & 14 \\
& C4S4 & V. high salinity-v. high alkali & 13 \\
& C3S2 & High salinity-med. alkali & 8 \\
Wadi & C3S1 & High salinity-low alkali & 3 \\
El-Natrun & C2S1 & Medium salinity-low alkali & 3 \\
& C4S2 & V. high salinity-med. alkali & 2 \\
& C3S3 & High salinity-high alkali & 2 \\
& C2S2 & Medium salinity-med. alkali & 2 \\
\hline & C3S1 & High salinity-low alkali & 25 \\
& C3S2 & High salinity-medium alkali & 10 \\
Tahrir & C2S1 & Medium Salinity-low alkali & 9 \\
& C4S2 & V.high salinity-medium alkali & 2 \\
& C4S1 & V.high salinity-low alkali & 1 \\
\hline Burg & C4S3 & High Salinity-high alkali & 22 \\
Al-Arab & C4S4 & V. high salinity-v. high alkali & 17 \\
& C4S2 & V.high salinity-med. alkali & 1 \\
\hline
\end{tabular}




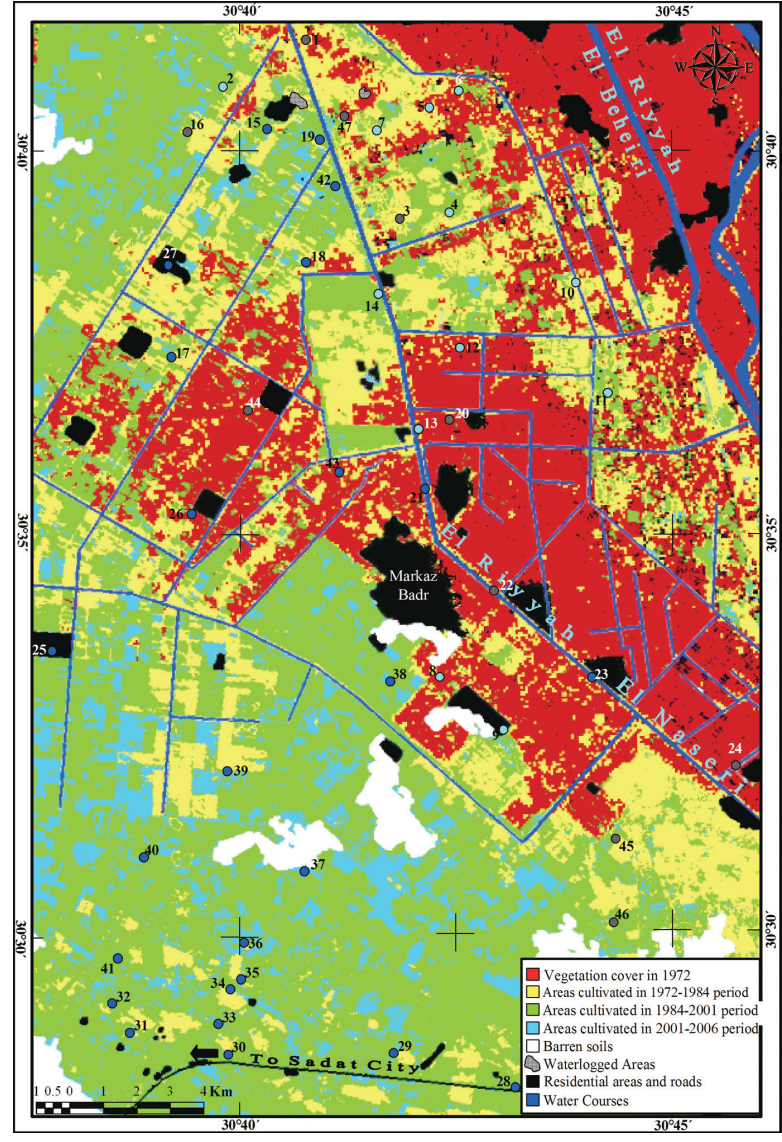

Fig. 6. Temporal agricultural expansions (1972-2006).

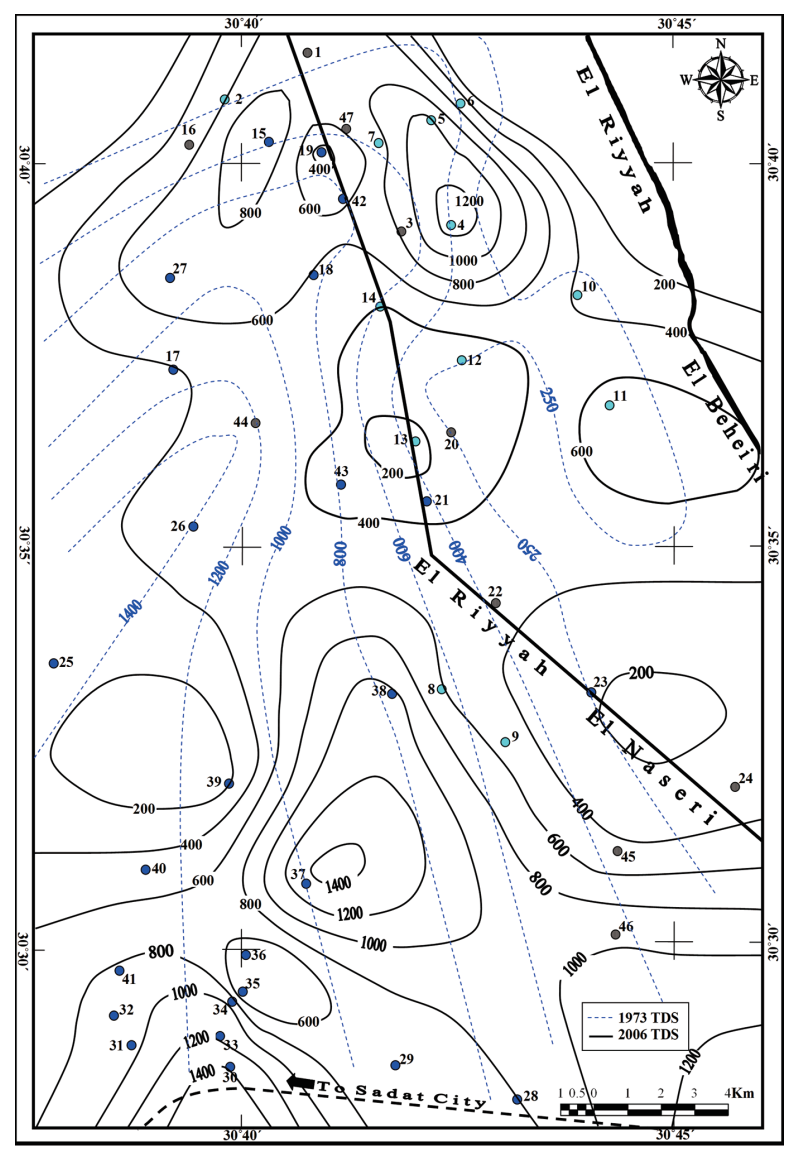

Fig. 8. Tahrir iso-salinity (mg/l) map produced applying the ordinary kriging technique.

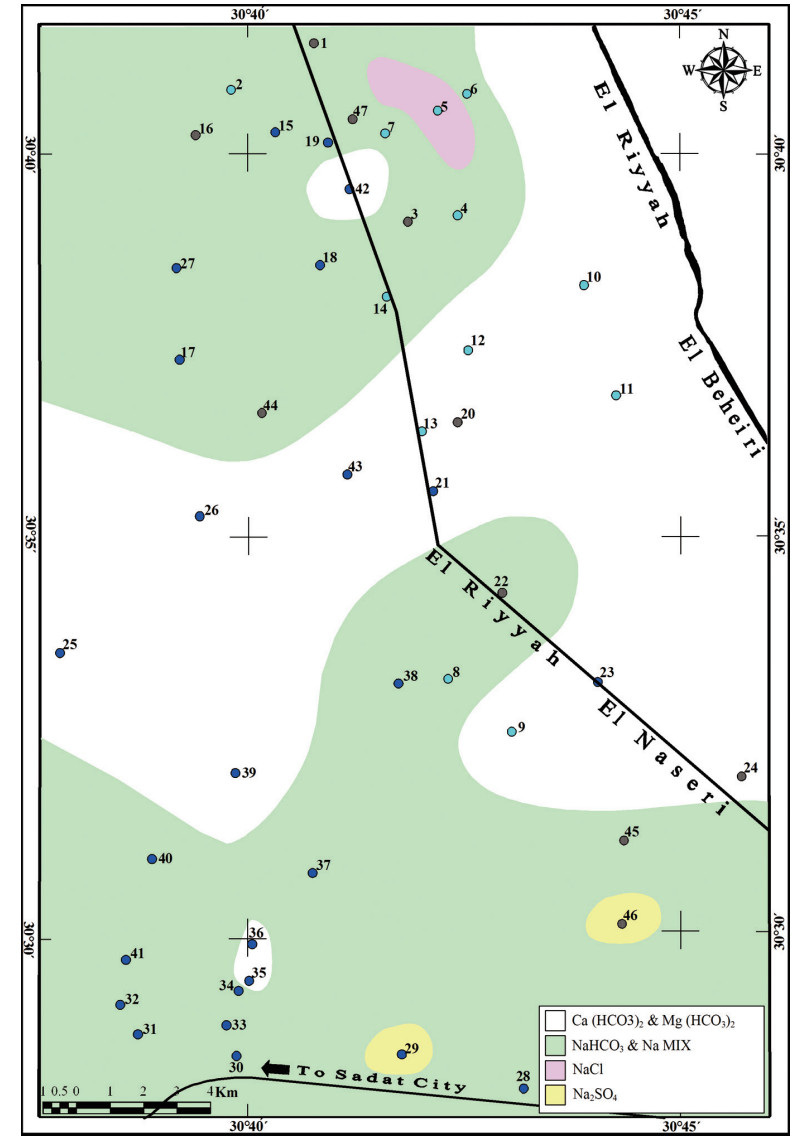

Fig. 7. Map of the groundwater types in Tahrir produced using the ordinary kriging technique.

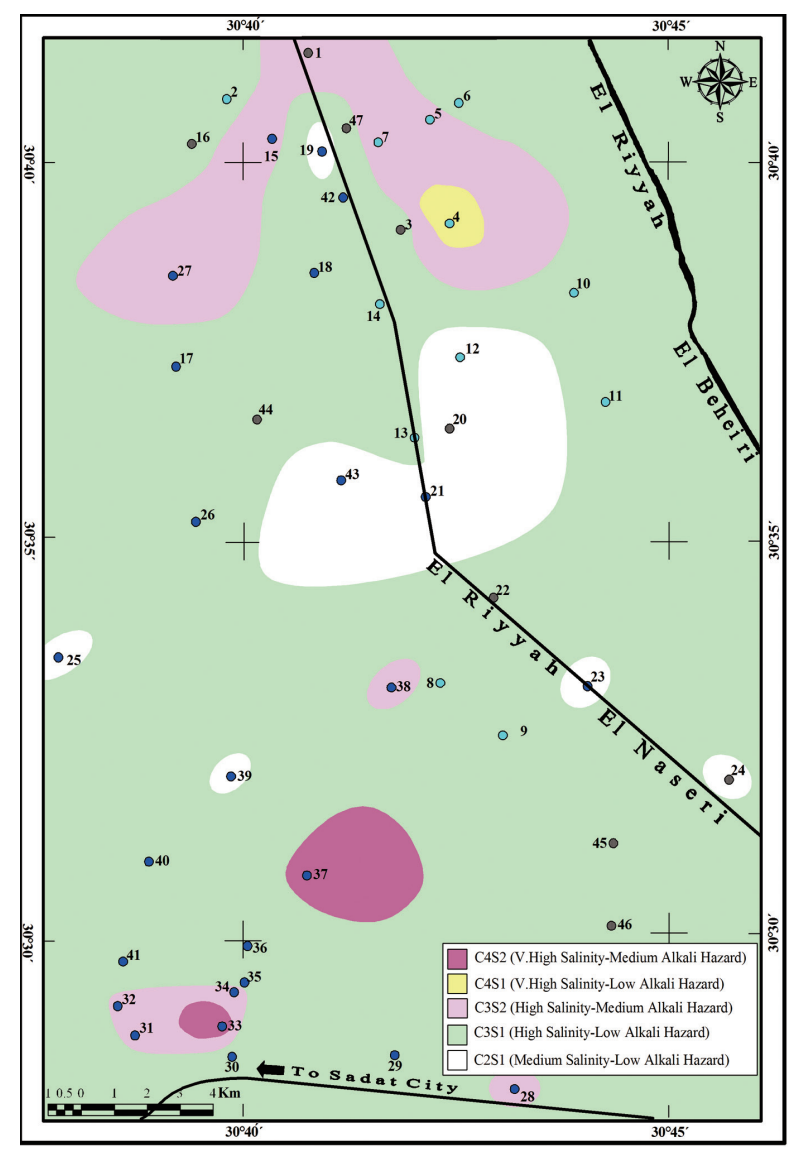

Fig. 9. Groundwater quality for irrigation use in Tahrir produced using the ordinary kriging technique. 


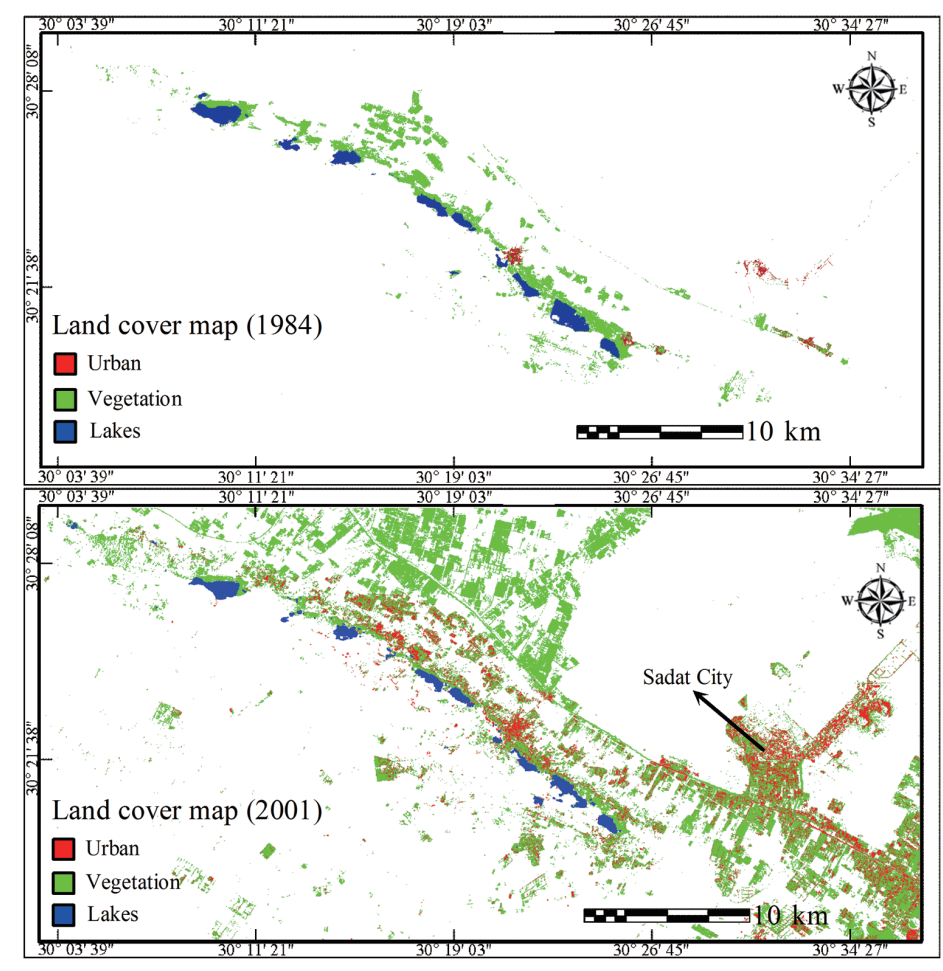

Fig. 10. Land use maps of Wadi El-Natrun area in 1984 and 2001.

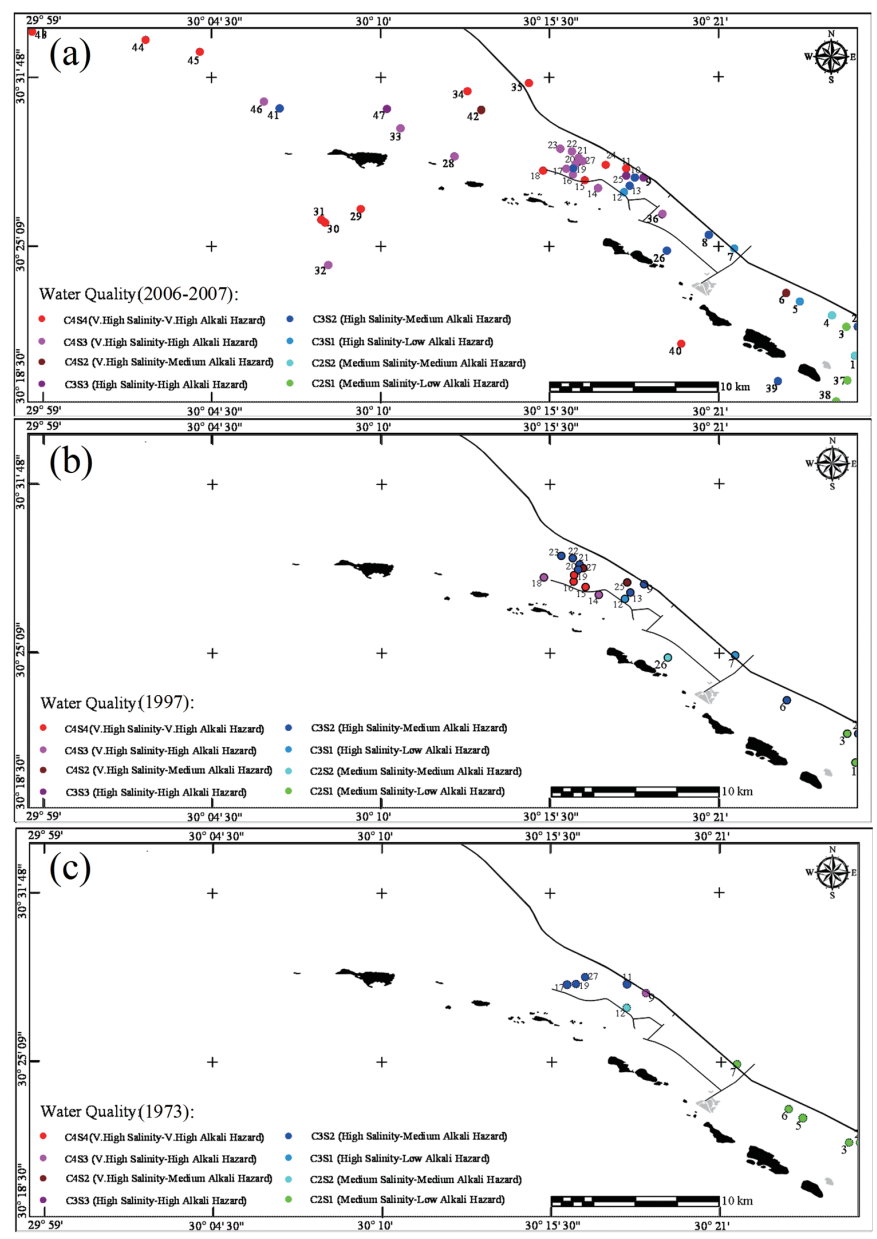

Fig.11. Temporal change in groundwater qualities for irrigation use in Wadi El-Natrun area. 
In Tahrir area, temporal salinity records of groundwater in the area showed an average of $496.5 \mathrm{mg} / \mathrm{l}$ in 1973 (El-Hinnawy and Atwa, 1973), $559.5 \mathrm{mg} / \mathrm{l}$ in 1983 (Abdel Baki, 1983), and reached the maximal value of $638.5 \mathrm{mg} / \mathrm{l}$ in 2006 , i.e. the total salt content of the Pleistocene aquifer has increased by 28 percent during the last 33 years. Iso-salinity maps for 1973 and 1983 were quite similar and showed a general trend of increasing salinity towards the southwestern part of the area. Map of 2006 TDS distinctly varied in the southern and the northern part (Fig. 8). These could be attributed mainly to over-exploitation of groundwater from the aquifers and to the complicated interrelationship between surface water and groundwater. Also, the average TDS showed gradual increase from the agricultural expansion before 1972 to the cultivation before 2006. In Burg Al-Arab, out of 77 samples recorded in May 1966 (Abdel Mogheeth, 1966); $\mathrm{NaCl}$ (52 samples), $\mathrm{CaSO}_{4}$ (21 samples), $\mathrm{Na}_{2} \mathrm{SO}_{4}$ (2 samples), $\mathrm{Mg}\left(\mathrm{HCO}_{3}\right)_{2}$ (1 sample), and $\mathrm{MgCl}_{2}$ (1 sample) water types were recognized. The $\mathrm{CaSO}_{4}, \mathrm{Na}_{2} \mathrm{SO}_{4}$, $\mathrm{Mg}\left(\mathrm{HCO}_{3}\right)_{2}$, and $\mathrm{MgCl}_{2}$ water types of the 1966 samples were turned into $\mathrm{NaCl}$ water in 2007 leading to intensive salinization of the aquifer. Changes in the characteristics of the 2007 water types on its evolution from the 1966 types confirmed the activity of seawater mixing, freshwater mixing, and gypsum dissolution processes. Salinity and alkalinity hazards are amplified and the water qualities are worsened from 1966 to 2007 as the result.

\section{Conclusions and Recommendations}

Based upon the trends under current management practices, the problems on fluctuations in water table levels and quality degradation described principally by water types dominated, salinity, nitrate concentrations, salinity/alkalinity hazards are regarded to continue to worsen the water quality in the studied areas. Although a general temporal trend of ever-deteriorating groundwater conditions was concluded, the spatial responses are variable depending on local factors for controlling each area's groundwater status.

In Wadi El-Natrun area, the results indicated that the increase in groundwater abstraction from the Pliocene aquifers and other surrounding aquifers (Pleistocene and Miocene) have had some negative impacts in some local areas. The flow system, the lithology, the geographic situation in relation to saline lakes, land use, the well design/maintenance, and overexploitation of the groundwater are all contributed to waterlevel declines and the chemical composition of groundwater. The results recommend the withdrawal from depths greater than $100 \mathrm{~m}$ to reach the lower fresh zone. Hydraulic properties via well-distributed pumping tests should be spatially understood to properly evaluate the aquifer. Professionals for construction and maintenance of wells should be involved in the evaluation process. Advanced numerical simulation using all the new available data should be applied to maximize the benefit of groundwater uses and to predict any possible negative impacts for a sustainable water resources.

In Tahrir area, the low specific yield in the upper parts of the aquifer will amplify the recharge the impact on water level and likely to be of greater magnitude than in the past. Also, with the rapid circulation of groundwater, concentrations of ions such as nitrate, sulphate, chloride, and sodium will increase with time. To mitigate against future recharge on the short-run and to sustain agricultural productivity and economic viability on the long-run will require a combination of strategies, i.e. districtbased allocation of groundwater and surface water budget should be undertaken considering specific characteristics of districts into account, adopting one or more changes in practice: improved irrigation scheduling to meet crop water requirements; improved conjunctive water use rules that accommodate irrigation water quality requirements; improved management of water delivery systems that minimize channel leakage; and where necessary, implementation of dewatering arrays and appropriate disposal of the extracted water. However, water table rise is inevitable, even in a well-managed irrigation system, because a leaching fraction is necessary to prevent salt accumulation in the root zone. Therefore, discharge into natural channels or constructed drains must be managed so that the water table does not rise to reach the soil surface. Also, adaptive management of groundwater under or down-gradient of irrigated areas where appropriate incentive mechanisms should be effective in place to ensure timely decisions in response to changes in water table level and groundwater quality.

In Burg Al-Arab, several superimposed and sequential sources of heterogeneities controlled the aquifer characteristics. Seawater mixing is proved by high TDS, $\mathrm{K}^{+}, \mathrm{Mg}^{2+}, \mathrm{Cl}^{-}$and $\mathrm{SO}_{4}{ }^{2-}$. Freshwater influx from effective rainwater infiltration and irrigation from surface canals are reflected by the lowered TDS, and $\mathrm{pH}$ values and high $\mathrm{HCO}_{3}{ }^{-}$concentrations in the cultivated areas. Dissolution of gypsum from the sabkha and salt march deposits showed marked increase in TDS, $\mathrm{Ca}^{2+}$, and $\mathrm{SO}_{4}{ }^{2-}$. $\mathrm{NaCl}$ and $\mathrm{Na}_{2} \mathrm{SO}_{4}$ water types dominated the area. Groundwater across the area was found unsuitable for irrigation use by the very high salinity associated with very high and high alkalinity hazards. These results suggest cultivation of salt tolerant crops. To mitigate the significant environmental problems in the study area, some countermeasures are needed to restore possible groundwater conditions to sustain agricultural productivity. Such countermeasures must be undertaken in the short term if we ensure also the sustainability of groundwater resource utilization. However, in order to maximize the potential of the outcomes from the present study area and in areas having similar 
hydrological conditions, further deliberate research is needed with proper spatio-temporal quantitative data regarding pumping rates, fertilizer uses, soil characteristics, and documented field management practices.

In addition to the proposed measures specific for each area, the national water policy and management plans and measures addressed in Abdel Gawad (2005) should be conducted without conflicting and overlapping of institutional functions. In order to strongly alleviate the devastating impacts of environmental degradation on water and land resources, five actions are possible: (1) conducting environmental impact assessments (EIA) before the commencement of the developmental projects that affect water conditions, (2) considering EIA for local specific spatio-temporal characteristics such as the geology, climate, land uses/land covers, water/agricultural practices and for setting efficiently at-risk areas priority and sustainability rules, (3) involving water resources professionals among the EIA expertise in all related fields beside decision makers in setting the assessment and management plans, (4) public availability of the results from completed governmental projects and from selffunded studies like the present case to enable spatio-temporal monitoring of aquifer conditions, and (5) enhancing and enforcing the legislation and regulations devoted to the water resources conservation.

\section{References}

Abdel-Baki, A. M. A. (1983) Hydrogeological and Hydrochemical Studies on the Area West of Rosetta Branch and South of ElNasr Canal. Ph. D. Thesis, Ain Shams University, Egypt, 156p. Abdel-Gawad, S. T. (2005) Water quality challenges facing

Egypt. Comparative Risk Assessment and Environmental Decision Making Nato Science Series: IV: Earth and Environmental Sciences, vol.38, pp. 335-347.

Ali, Y. A., and West, I. (1983) Relationships of modern gypsum nodules in sabkhas of loess to compositions of brines and sediments in northern Egypt. Journal of Sedimentary Petrology, vol.53, no.4, pp.1151-1168.

American Public Health Association (APHA) (1989) Standard Methods for the Examination of Water and Wastewater, $17^{\text {th }}$ edition. APHA, Washington, DC.

Awad, M. A., Sallouma, M. K., Gomaa, M. A., and Ezz El-Din, M. R. (1997) Comparative hydrogeochemical and isotopic studies on groundwater in Wadi El-Farigh and Wadi El-Natrun at the fringes of Western Nile Delta, Egypt. El-Minia Science Bulletin, vol.10, no.1, pp.1-22.

Chavez, G. L. (1982) Statistical method for selecting LANDSAT MSS ratios. Journal of Applied Photographic Engineering, vol.8, no.1, pp.23-30.

CONOCO (1987) Geological Map of Egypt (scale $1: 50,000$,
NH 36 NW Cairo). The Egyptian General Petroleum Corporation.

El-Awady, M. M., Atwia, M. G., El-Nikhely, A. H., and Hamouda, A.Z. (1997) Chemistry of groundwater in Wadi El-Natrun area, Western Desert, Egypt. The Third Conference on Geochemistry, Sept. 3-4, Alexandria University, Faculty of Science, vol.3, pp.57-67.

El-Hinnawi, E. E., and Atwa, S. M. (1973) Geochemistry of ground waters from some localities west of the Nile Delta. Geologische Rundschau, vol.62, pp.225-245.

El-Shazly, E. M., Abdel Hady, M. A., El-Shazly, M. M., Sanad, S., El-Ghazawi, M. M., and Abdel Mogheeth, S. M. (1978) Subsurface Geology and Geochemistry of PlioceneQuaternary Aquifers in Northwest Nile Delta Area. Remote Sensing Center, Academy of Scientific Research and Technology, Cairo, 258p.

Gao, X., Huete, A. R., Ni, W., and Miura, T. (2000) Opticalbiophysical relationships of vegetation spectra without background contamination. Remote Sensing of Environment, vol.74, no.3, pp. 609-620.

General Petroleum Company (1978) The Groundwater Resources of Wadi El-Natrun area, Western Desert, Egypt. Unpublished report, 82p.

Hantar, G. (1990) North Western Desert. In: Geology of Egypt (ed. R. Said), A. A. Balkema, Rotterdam, pp.293-327.

Hilmy, E., El Shazly, M. M., Tamer, M. A., and Korany, E. A. (1977) Contribution to the hydrogeology of the water bearing formations in the area between Burg El Arab and El-Daba'a, Western Desert, Egypt. Bulletin Desert Institute, Egypt, vol.27, no.2, pp. 53-72.

Huete, A. R. (1988) A soil-adjusted vegetation index (SAVI). Remote Sensing of Environment, vol.25, pp.295-309.

Kauth, R. J., and Thomas, G.S. (1976) The Tasseled Capa graphic description of the spectral-temporal development of agricultural crops as seen by Landsat. Proceedings of the Symposium on Machine Processing of Remotely Sensed Data, pp. 4041-4051.

Masoud, A.A., and Atwia, M.G. (2010) Spatio-temporal characterization of the Pliocene aquifer conditions in Wadi ElNatrun Area, Egypt. Journal of Environmental Earth Sciences, vol.62, no.7, pp.1361-1374.

Omara, S. M., and Sanad, S. (1975) Rock stratigraphy and structural features of the area between Wadi El-Natrun and the Moghra depression, Western Desert, Egypt. Geol. Jb., Hannover, B.16, pp.45-73.

Piper, A. M. (1944) A graphical procedures in the geochemical interpretation of water analysis. Trans. Am. Geophys. Union, vol.25, pp.914-928.

Rashed, G. A., El-Dessouky, M. M., Ashry, H. A., and El-Bagawy, 
C. M. (1989) Trace metals in sediments from El-Rayah ElTawfiky and some of its extensions. Egyptian Journal of Engineering, vol.4, no.1, pp.1-15.

Rashed, M. A. (1991) Engineering - geological properties of Pliocene argillaceous sediments of the wadi El-Natrun Area (Egypt). Bulletin of the International Association of Engineering Geology, vol.44, pp.69-77.

Research Institute for Ground Water (RIGW) (1990) Hydrogeological map of Egypt, West Tanta, Scale 1 : 100,000, El Kanater El Khairia, Egypt.

Research Institute for Ground Water (RIGW) (1992) Hydrogeological map for the Nile Delta area, Scale 1 : 500,000, El Kanater El Khairia, Egypt.

Saad, E.E. (2001) Use of mathematical modeling for water resources management in the area west of El-Nubariya Canal, Egypt. Proceedings of the Arab-Workshop on Application of mathematical modeling techniques for management and planning of water resources, Ministry of Agriculture and Land
Reclamation, Desert Research Center, Cairo, Egypt, 10-15 March 2001, 31p.

Sanad, S. (1973) Geology of the Area between Wadi El-Natrun and the Moghra Depression. Ph. D. Thesis, Assuit University, 185p.

Shata, A. (1955) An introductory note on the geology of the northern portion of the Western Desert. Bull. De L'Institute Du Desert D'Egypte, vol.5, no.3, pp.87-98.

Stanley, D. J., and Hamza, F. H. (1992) Terrigenous-carbonate sediments interface (Late Quaternary) along the northwestern margin of the Nile Delta, Egypt. Journal of Coastal Research, vol.8, no.1, pp.153-171.

Tucker, C. J. (1979) Red and photographic infrared linear combinations for monitoring vegetation. Remote Sensing of Environment, vol.8, pp.127-150

United States Salinity Laboratory Staff (1954) Diagnosis and Improvement of Saline and Alkali Soils. U.S. Department of Agriculture, Washington D. C., Handbook 60, 160p. 